\title{
Magdalena Żołędziejewska
}

(Uniwersytet im. A. Mickiewicza w Poznaniu, Poznań - Polska)

\section{KATEGORIA MASKI W POWIEŚCI BIESY F.M. DOSTOJEWSKIEGO}

"Choć Dostojewski nie napisał ani jednej strony w formie dramatu, nie mniej jednak w swych powieściach jawił się jako wielki tragik"1. Tymi słowami twórczość Fiodora Dostojewskiego scharakteryzował Siergiej Bułgakow, odnosząc się szczególnie do powieści Biesy, którą mimo braku wspomnianej formy dramatycznej, określał mianem tragedii. Zjawisko teatralizacji świata przedstawionego, czy też motyw odgrywania roli przez bohaterów dzieł Dostojewskiego stanowią obiekt badań wielu literaturoznawców. Kategoria maski, będąca tematem niniejszego artykułu, w większości przypadków, również w Biesach, omawiana jest w kontekście konceptu teatru i gry aktorskiej.

Na szczególną uwagę zasługuje postać głównego bohatera Nikołaja Stawrogina, którego twarz innym bohaterom powieści przypomina maskę. Jako maskę postrzegają oni również całą jego osobowość, postawę wobec otaczającego świata. Dlatego też, analizując motyw maski na przykładzie Stawrogina, warto zastanowić się nad interpretacją maski osadzonej w rosyjskiej kulturze prawosławnej oraz maską rozumianą jako persona $\mathrm{w}$ badaniach psychologii analitycznej.

Maska w rozumieniu prawosławnej filozofii Wieku Srebrnego, łączona jest $\mathrm{z}$ teologią trynitarną, którą najpełniej wyrażają pojęcia lik, lico i liczina, najczęściej pojawiające się przy omawianiu ikonopisarstwa. Najważniejszą częścią triady, z religijnego punktu widzenia, jest niewątpliwie lik, określany jako boże podobieństwo. Warto podkreślić różnicę pomiędzy pojęciami boże podobieństwo (божье подобие) a boży obraz (божий образ). Według Florenskiego bożym obrazem nazywamy twarz (lico), w której może realizować się boże podobieństwo, tj. lik. Najbardziej znaczącym w kontekście omawianej kategorii elementem triady jest liczina, rozumiana jako maska, którą Paweł Florenski przeciwstawia pojęciu lik. Ponadto, zauważa on, iż liczina-maska mimo podobieństwa do lica-twarzy, w rzeczywistości jest w środku pusta. Oszukuje obser-

${ }^{1}$ С.Н. Булгаков, Русская трагедия, http://www.vehi.net/bulgakov/tragediya.html (25.02. 2012) (tłum. własne) oryg. „Хотя Достоевский не написал ни одной страницы в драматической форме, тем не менее в своих больших романах по существу дела он является и великим трагиком". 
watorów przekłamanym obrazem lub też pokazuje coś, co w ogóle nie istnieje. Maska w prawosławnej filozofii Wieku Srebrnego jest utożsamiana również z grzechem ${ }^{2}$. Z kolei według słów innego filozofa tej epoki Nikołaja Bierdiajewa, przywdziewanie maski-licziny wiąże się także $\mathrm{z}$ chęcią skrycia przed otaczającym człowieka światem³ ${ }^{3}$.

$\mathrm{Z}$ drugiej zaś strony, można mówić o masce $\mathrm{z}$ punktu widzenia psychologii analitycznej Carla Gustawa Junga, w której to maskę rozumie się pod pojęciem persony. Zgodnie z twierdzeniem szwajcarskiego psychologa, pojęcie persony można odnieść do systemu relacji między jednostką a społeczeństwem. Należy zauważyć, iż zadaniem persony, z jednej strony, jest to wywieranie na otoczeniu konkretnego wrażenia, a z drugiej - ukrywanie prawdy o jednostce. Nie powinno być nadużyciem stwierdzenie, iż persona umożliwia odegranie pewnej osobowości - zarówno osobie posługującej się persona, jak i jej obserwatorom. Wykorzystywanie persony w kontaktach z otaczającym nas światem, sprzyja wytworzeniu rzeczywistości wtórnej, umownej. Persona nie jest tym, kim człowiek jest naprawdę, a jedynie percepcją danej osoby przez nią samą lub przez jej otoczenie 4 .

Właśnie w kluczu przedstawionych badań i teorii została przeze mnie przeanalizowana postać protagonisty dzieła Dostojewskiego - Nikołaj Stawrogin. Pierwsza z interpretacji zakłada pojmowanie maski z punktu widzenia prawosławnej filozofii Wieku Srebrnego, w której to liczina Stawrogina może świadczyć o jego grzesznej osobowości. Już przy pierwszym spotkaniu ze Stawroginem na kartach powieści, narrator zwraca uwagę czytelnika na wyróżniającą się w tłumie twarz-maskę głównego bohatera. Od samego początku maska jest atrybutem przypisanym Stawroginowi, poprzez który można rozpatrywać jego zachowanie i osobowość. Warto zwrócić uwagę na fakt, iż już w staroruskiej cerkwi maskę kojarzono z twarzą diabła, a samo jej przywdziewanie stanowiło ciężki, wymagający odkupienia grzech ${ }^{5}$. Tak też można postrzegać maskę na stawrogińskiej twarzy - z czarnymi włosami, jasnymi oczami i bladą twarzą - „Chłopiec jak malowanie, a jednocześnie dziwnie jakoś odrażający”6.

O grzesznym, czarcim charakterze maski Nikołaja Stawrogina, może świadczyć fakt, iż napawa ona lękiem bliskie mu osoby - Marię Liebiad-

2 П. Флоренский, Иконостас, http://www.vehi.net/florensky/ikonost.html (25.02.2012).

${ }^{3}$ H.A. Бердяев, Я и мир объектов, http://www.vehi.net/berdyaev/mirobj/05.html (26.02. 2012).

${ }^{4}$ К.Г. Юнг, Отношения между я (эго) и бессознательным, http://jungland.ru/node/1493 (21.05.2012).

${ }^{5}$ Б. Успенский, Семиотика истории. Семиотика культуры, http://www.gumer.info/ bibliotek_Buks/Culture/Ysp/05.php (22.04.2012).

${ }^{6}$ F.M. Dostojewski, Biesy, tłum. T. Zagórski, Z. Podgórzec, Warszawa 1992, s. 43. 
kinę, a przede wszystkim jego matkę. Potwierdzeniem tego, iż maskę Stawrogina można określić jako liczine pokazującą jego grzeszną osobowość i jednocześnie skrywającą duchową pustkę, są przede wszystkim spostrzeżenia ludzi z jego towarzystwa. Uważają oni, iż Stawrogin żyje po to, by dopuszczać się grzechów i krzywdzić innych. Przykładem takiego myślenia są niewątpliwie słowa Aleksieja Jegorycza, skierowane do Nikołaja:

Niech Bóg pana błogosławi, lecz tylko w cnotliwych zamierzeniach?.

Ta sytuacja udowadnia, iż otoczenie odbiera Stawrogina jako osobę zdolną do popełnienia grzechu, czy wyrządzenia krzywdy innym. Nie są to mylne sądy - dla żartu wstąpił w związek małżeński z Marią Timofiejewną, co może wskazywać na brak szacunku dla ludzkich uczuć. Ponadto, Stawrogin nie potrafi dokonać wyboru między biegunami dobra i zła8, zarówno w jednym jak i w drugim szuka piękna i przyjemności, do czego przyznaje się w swojej „spowiedzi”. Grzeszną maskę-liczinę Stawrogina można także uważać za skutek szaleństwa lub opętania. Przed przytoczeniem słów stawrogińskiej spowiedzi, narrator uprzedza czytelnika, że dokument ten jest wypaczonym dziełem biesa, który zawładnął głównym bohaterem.

Jednakże warto również zwrócić uwagę na sytuację, w których Nikołaj Stawrogin chce zrzucić z siebie maskę i odkupić grzechy. W rozmowie $z$ Tichonem przyznaje, iż przede wszystkim pragnie sam przebaczyć sobie swoje złe postępowanie, i dlatego też szuka cierpienia, wierzy, że poprzez nie może zbawić swoje sumienie. $Z$ drugiej zaś strony, pojawia się pytanie, czy zamiary Stawrogina są w pełni uczciwe, gdyż zdaje się w to wątpić nawet Tichon. Nikołaj bardziej boi się tego, że zapamiętane zostanie jedynie to, co śmieszne i miałkie $\mathrm{w}$ jego działaniach, natomiast nie zastanawia go aspekt moralny swojego zachowania. Dlatego też można za Nikołajem Bierdiajewem stwierdzić, że dla świadomości i etyki prawosławnej Stawrogin zginął bezpowrotnie9.

Ciekawym jest niewątpliwie fakt, iż oprócz licziny, niektórzy z otoczenia Stawrogina przypisują mu lik. Wspomniany Bierdiajew zauważył, że są wśród bohaterów Biesów i tacy, którzy wielbią Stawrogina niczym boga. Fiedka Katorżny przyznaje, że stoi przed Nikołajem jak przed „Panem Bogiem"10. Podobne odczucia wobec głównego bohatera żywi Piotr Wierchowieński, traktujący Stawrogina jak swojego idola.

7 Ibidem, s. 213

${ }^{8}$ H.А. Бердяев, Ставрогин, http://www.vehi.net/berdyaev/stvrogin.html (26.02.2012).

${ }^{9}$ Ibidem.

${ }^{10}$ F.M. Dostojewski, op. cit., s. 239. 
Analizując postać Nikołaja Stawrogina z punktu widzenia osiągnięć psychologii analitycznej można dostrzec, iż główny bohater powieści nakłada maskę-personę $\mathrm{z}$ jednej strony $\mathrm{w}$ celu ukrycia swojej prawdziwej twarzy, zaś z drugiej z zamiarem wywarcia określonego wrażenia na otoczeniu. Jednakże, trudno jest nie zauważyć, że ów drugi „zamiar” jest wynikiem tego, czego w rzeczywistości społeczeństwo oczekuje od Stawrogina. Przywdziewanie persony jest poniekąd jego obowiązkiem nałożonym nań przez ludzi z jego otoczenia. Stawrogin odczuwa to, zastanawiając się, dlaczego wszyscy oczekują od niego rzeczy, których nie oczekiwaliby od innych. Z tego powodu, protagonista Biesów dysponuje całą gamą masek, które dobiera zależnie od sytuacji, w której się znajduje lub będzie znajdował.

Wartym podkreślenia jest fakt, iż są chwile, kiedy Stawrogin decyduje się pokazać swoją własną twarz, nie odgrywa żadnej roli, a zwłaszcza takiej, w której najchętniej oglądałoby go otoczenie. Właśnie w takich sytuacjach ludzie $\mathrm{z}$ jego towarzystwa odczuwają pewien dyskomfort, jak np. wówczas, gdy Nikołaj przyznaje, iż z Marią Liebiadkiną łączą go więzy małżeńskie. $\mathrm{O}$ tym, że maska bohatera jest jego personq świadczyć może też fakt, iż inni ludzie chcą widzieć w nim kogoś innego, Piotr Wierchowieński chce uczynić z niego Iwana Carewicza, jego matka dostrzega w nim coś z księcia Harry'ego z szekspirowskiej sztuki. Nawet w oczach bliskich mu ludzi, Stawrogin nie jawi się zupełnie jako on sam, tylko jako różne persony, narzucane mu przez otoczenie.

Można odnieść wrażenie, iż sam Nikołaj Stawrogin bardziej postrzega siebie poprzez pryzmat persony, którą się posługuje, można dostrzec $\mathrm{w}$ jego zachowaniu cechy świadczące o jego zżyciu się z odgrywaną przez niego rolą społeczną. Ten fakt może stanowić niebezpieczeństwo dla samego bohatera, jako że zdaje się, iż Stawrogin nie boi się śmierci, co widać podczas pojedynku. Być może to, iż nie odczuwa on strachu przed śmiercią jest efektem tego, że bardziej myśli o sobie jak o personie, o tym, że to ona polegnie, a nie prawdziwy Nikołaj Stawrogin.

Dzięki analizie głównego bohatera w świetle osiągnięć psychologii analitycznej Junga, można stwierdzić, iż jego negatywne zachowanie nie jest w pełni jego winą. Tak też uważa Barbara Pietrowna, która broni swojego syna, twierdząc iż to towarzystwo w jakim przebywa Nikołaj ma na niego zgubny wpływ. To ono oczekuje, a wręcz żąda od niego, by odgrywał rolę złego człowieka.

Podczas rozmowy-spowiedzi u Tichona Stawrogin chce wziąć całą winę na siebie, napominając o swojej rozszczepionej osobowości, o tym, iż podczas popełniania grzechów to był on, tylko w różnych postaciach. Innym zaś razem twierdzil, że jego rolą jest odgrywanie szaleńca, lub też, iż jego zachowanie jest wynikiem działania biesa. Można zatem 
zauważyć u Stawrogina oznaki rozstrojenia psychicznego, neuroz, wywołanych przez mnogość person lub też przez rozpad persony, czego przejawem są fobie i natręctwa (np. ciągłe przywoływanie obrazu Matrioszy).

Także w zachowaniu innych bohaterów Biesów można dostrzec posługiwanie się personą. Otoczenie $\mathrm{w}$ powieści zdaje się wpływać prawie na wszystkich bohaterów. Marionetką w rękach Barbary Pietrowny jawi się Stiepan Trofimowicz, ona zaś doskonale czuje się w roli reżysera życia starszego Wierchowieńskiego. Syn Stiepana - Piotr jest postacią, która niezwykle umiejętnie radzi sobie ze swoimi rolami w społeczeństwie. Nawet kiedy mówi, że tym razem zdecydował o zachowaniu swojej prawdziwej twarzy, zdaje się iż jego prawdziwe „ja” również jest jedną z jego ról. Młody Wierchowieński manipuluje także obrazem Stawrogina w oczach innych ludzi. Mówiono o nim, iż potrafi stworzyć swój własny obraz danego człowieka i z nim żyć i, zdaje się, że tego właśnie dokonał w przypadku Nikołaja Stawrogina.

Podsumowując, starałam się przedstawić kategorię maski w powieści Fiodora Dostojewskiego Biesy w ujęciu dwóch idei - prawosławnej filozofii Srebrnego Wieku oraz psychologii analitycznej C.G. Junga, ze szczególnym uwzględnieniem przykładu głównego bohatera powieści.

Pierwsza teza opiera się na prawosławnej filozofii Srebrnego Wieku, w którą wpisuje się także pojęcie teologii trynitarnej, odnoszącej się do terminów lik, lico i liczina. Liczina określana jest jako rodzaj maski i może być utożsamiana z grzechem. Tak rozumiana maska posłużyła percepcji głównego bohatera Biesów jako człowieka grzesznego, którego złe postępowanie pochodzi z jego wnętrza. Warto jednak dodać, iż według Nikołaja Bierdiajewa możliwe jest wywyższenie poprzez grzech, ale tylko wówczas gdy osoba, która go popełniła jest tego świadoma. Świadomość bowiem jest w tym wypadku źródłem cierpienia, które może doprowadzić do odkupienia grzechu11.

Druga koncepcja maski opiera się na osiągnięciach psychologii analitycznej Carla Gustava Junga, z wyszczególnieniem pojęcia persona, to jest części nieświadomości zbiorowej. Persona w ujęciu psychologii analitycznej oznacza swojego rodzaju maskę nakładaną przez człowieka, potrzebną mu do interakcji w społeczeństwie. Może być również postrzegana jako rola społeczna danej osoby narzucona jej przez otoczenie ${ }^{12}$. Tak przeprowadzona analiza pokazała, iż maska Stawrogina może być rozpatrywana jako narzucone przez społeczeństwo role, co sprawia, że

${ }_{11}$ Н.А. Бердяев, О назначении человека, http://www.gumer.info/bogoslov_Buks/Philos /Berd/_Nazn_02.php (24.06.2012).

12 К.Г. Юнг, ор. cit. 
nie należy postrzegać głównego bohatera powieści Dostojewskiego jako osoby całkowicie pejoratywnej.

Interpretacja przeprowadzona $\mathrm{w}$ kontekście wyżej wymienionych sposobów ujęcia kategorii maski udowodniła, iż postać Stawrogina może być postrzegana zarówno poprzez pryzmat religii prawosławnej oraz psychologii analitycznej, gdzie postawa głównego bohatera analizowana jest z punktu widzenia relacji między nim a społeczeństwem, w którym żyje. 